\title{
Hairy Vetch and Livestock Compost Improve Soil Carbon and Nitrogen, and Fresh-market Tomato Yield
}

\author{
Rafael A. Muchanga \\ Graduate School of Environmental Science, Hokkaido University, Sapporo \\ 060-0810, Japan
}

\author{
Toshiyuki Hirata and Hajime Araki ${ }^{1}$ \\ Field Science Center for Northern Biosphere, Hokkaido University, Sapporo \\ 060-0811, Japan
}

Additional index words. cover cropping, $\mathrm{N}$ management, $\mathrm{N}$ uptake, $\mathrm{N}$ recovery, soil quality

\begin{abstract}
Cover crops and compost application may influence soil quality and productivity of fresh-market tomatoes. The effects of hairy vetch (HV) (Vicia villosa Roth) and livestock compost on soil $\mathrm{C}$ and $\mathrm{N}$ stocks, $\mathrm{N}$ availability, and tomato yield were evaluated for 2 years in a plastic high tunnel. Averaged across years, soil $\mathrm{C}$ and $\mathrm{N}$ stocks increased in plots incorporating hairy vetch and compost more than in plots with no hairy vetch and compost. When compared with baseline stocks (initial soil $\mathrm{C}$ and $\mathbf{N}$ stocks before the initiation of the examination), soil $C$ stock increased by $3 \%, 2.8 \%, 2.6 \%$ in the $\mathrm{HV}$ treatment, the compost treatment, and the $\mathrm{HV}$ and compost treatment, respectively. In contrast, a $1.85 \%$ loss of soil $C$ stock was observed in a no $\mathrm{HV}$ and no compost (bare) treatment. Soil $\mathbf{N}$ stocks increased in all treatments, with the greatest increase in the compost treatment $(26 \%)$ and the lowest in the bare treatment $(9.3 \%)$. Averaged across sampling dates, the HV treatment exhibited the greatest soil $\mathrm{N}$ availability and nitrate levels in leaf petiole in both years, whereas the bare treatment exhibited the lowest soil $\mathbf{N}$ availability and nitrate levels in leaf petiole. HV + compost and compost treatments showed a similar influence on soil $\mathrm{N}$ availability, but $\mathrm{HV}+$ compost exhibited greater nitrate levels in leaf petiole than the compost treatment. The marketable and total yields were $10 \%$ to $15 \%$ greater in the $\mathrm{HV}$ and the compost treatments than in the bare treatment. $\mathrm{N}$ uptake was $17 \%$ to $38 \%$ greater in the $\mathrm{HV}$ treatment than in the other treatments. Because of unstable cover crop production in the northern region, a combined application of cover crops and compost may be one of the best practices to compensate for low cover crop biomass production by increasing organic matter input to the soil, thereby improving soil quality and tomato yield.
\end{abstract}

Improving soil quality and crop productivity is central to sustainable agriculture (Kuo et al., 2001). Management practices such as cover cropping and compost application can influence tomato yield and soil quality. Cover crops can maintain or increase organic $\mathrm{C}$ and $\mathrm{N}$ concentrations in the soil by increasing input of organic matter to the soil (Hargrove, 1986; Kuo et al., 1997a; Sainju et al., 2000). Legume cover crops such as HV can supply $\mathrm{N}$ to succeeding crops and increase crop yields compared with nonlegumes or bare fallow (Abdul-Baki et al.,

Received for publication 18 Dec. 2018. Accepted for publication 6 Mar. 2019.

This research was supported by a Grant-in-Aid for Scientific Research (no. 18H02310) provided by JSPS (Japan Society for the Promotion of Science). We thank Hideki Nakano, technical staff at the Field Science Center for Northern Biosphere, Hokkaido University, for technical assistance in tomato production.

${ }^{1}$ Corresponding author. E-mail: araki@fsc.hokudai. ac.jp.

This is an open access article distributed under the CC BY-NC-ND license (https://creativecommons.org/licenses/by-nc-nd/4.0/).
1996; Araki et al., 2009; Kuo et al., 1997b). By providing additional $\mathrm{N}$ to succeeding crops, HV may contribute to the reduction of synthetic $\mathrm{N}$ fertilizer application in crop production. For similar reasons, compost application is seen as a promising practice in tomato production systems. Previous studies have shown increased soil $\mathrm{C}$ concentrations when manures or composts were applied in the soil compared with bare fallow (Albaladejo et al., 2008; Brown and Cotton, 2011; Kong et al., 2005). Moreover, the use of livestock compost in crop production is a costeffective means of sequestering $\mathrm{C}$ (Brown and Cotton, 2011) and recycling of animal waste that otherwise could pose risks to the environment. A combined application of cover crops and compost residues may be an effective practice to increase the quantity of organic matter added to the soil, which affects soil C and N dynamics (Paustian et al., 1992), as well as reduce the cover crop seeding cost because a reduced seeding rate is used in the mixture.

Despite the potential of cover crops and compost to improve soil organic $\mathrm{C}$ and $\mathrm{N}$, and crop productivity, research on their use in plastic high-tunnel systems is still limited. However, the production area of vegetables grown in plastic high tunnels, such as tomatoes, is expanding in the northern hemisphere, especially in China, Japan, and South Korea (Costa and Heuvelink, 2018; Wittwer, 1993). Plastic high-tunnel systems differ from openfield systems in crop management level and environmental conditions. The temperature is relatively stable and higher in a plastic high tunnel than in the open field; therefore, cover crops may grow better in a plastic high tunnel than in the open field. Because soil $\mathrm{C}$ or $\mathrm{N}$ sequestration is correlated with the amount of residues returned to the soil (Campbell et al., 2001; Kuo et al., 1997b), changes in soil C and $\mathrm{N}$ may be more pronounced in a plastic high tunnel than in the open field.

Quantifying soil $\mathrm{C}$ and $\mathrm{N}$ as stocks is essential to understand changes in the whole soil $\mathrm{C}$ and $\mathrm{N}$ pools as affected by management practices such as cover cropping and compost application. The quality of organic residues applied to the soil $(\mathrm{N}$ content or $\mathrm{C}: \mathrm{N}$ ratio) is a key factor affecting soil $\mathrm{N}$ availability, $\mathrm{N}$ uptake, and crop productivity (Hargrove, 1986; Paustian et al., 1992; Ranells and Wagger, 1996). Thus, given the differences in $\mathrm{C}$ and $\mathrm{N}$ concentrations, and decomposition speed between livestock compost and $\mathrm{HV}$, they may influence differently the soil $\mathrm{C}$ and $\mathrm{N}$ pools, $\mathrm{N}$ uptake, and tomato yield. Our research hypotheses were as follows: 1) because of the greater $\mathrm{C}$ and $\mathrm{N}$ inputs, $\mathrm{HV}$ and compost treatments may increase soil $\mathrm{C}$ and $\mathrm{N}$ stocks compared with a bare treatment; and 2) because of a lower decomposition speed, compost may be more effective in increasing soil $\mathrm{C}$ and $\mathrm{N}$ stocks than HV. In turn, HV vetch with a greater $\mathrm{N}$ concentration and decomposition speed may be more effective in increasing soil $\mathrm{N}$ availability, $\mathrm{N}$ uptake, and tomato yield than compost. Combining both HV and compost would lead to increased $\mathrm{C}$ and $\mathrm{N}$ stocks, as well as increased soil $\mathrm{N}$ availability, $\mathrm{N}$ uptake, and tomato yield. The objectives of the study were to evaluate the effects of $\mathrm{HV}$ and livestock compost on tomato yield and $\mathrm{N}$ uptake, soil $\mathrm{N}$ availability, and soil $\mathrm{C}$ and $\mathrm{N}$ stocks.

\section{Material and Methods}

Site and experimental design. The experiments were conducted for two consecutive years (2015-16 and 2017) at the Experimental Farm of the Field Science Center for Northern Biosphere, Hokkaido University, Sapporo (snow cover region), Japan, on an Andisol with a clay loam texture. The experiments were conducted in a plastic high tunnel $(17.5 \times 6.5 \times 3.5 \mathrm{~m})$, and the chemical properties of the soil were as follows: $26.5 \mathrm{mg} \mathrm{NO}{ }^{-}-\mathrm{N}, 18.5 \mathrm{mg} \mathrm{NH}_{4}^{+}-\mathrm{N}, 0.87 \mathrm{~g}$ $\mathrm{K}, 3.69 \mathrm{~g} \mathrm{Ca}, 0.59 \mathrm{~g} \mathrm{Mg}$, and $0.27 \mathrm{~g} \mathrm{P}$ (Truog$\mathrm{L}$ method)/kg dry soil taken at a depth of 0 to $10 \mathrm{~cm}$ before the initiation of the experiment. Soil total $\mathrm{C}$ and $\mathrm{N}$ percentages were $3.09 \%$ and $0.21 \%$, respectively, and $\mathrm{pH}(1: 2.5 \mathrm{w} / \mathrm{v})$ and electrical conductivity $(1: 5 \mathrm{w} / \mathrm{v})$ were 6.53 and $14.9 \mathrm{mS} \cdot \mathrm{m}^{-1}$, respectively. The soil and air temperatures (inside and outside the plastic high tunnel) measured during the 
period of tomato cultivation in 2016 and 2017 are presented in Fig. 1. The soil and air temperatures in the plastic high tunnel were measured at a $10-\mathrm{cm}$ depth and a $1.5-\mathrm{m}$ height, respectively, by means of a data logger (midi Logger GL820; Graphtec Co., Yokohama, Japan); the outside soil and air temperatures were obtained from the weather station set at the Experimental Farm, Field Science Center for Northern Biosphere, Hokkaido University, Sapporo, Japan. The field plots were assigned the same treatments in the two growing seasons. The treatments consisted of HV planted at the full seeding rate of $20 \mathrm{~kg} \cdot \mathrm{ha}^{-1}$, livestock compost, a mixture of $\mathrm{HV}$ planted at half the seeding rate $\left(10 \mathrm{~kg} \cdot \mathrm{ha}^{-1}\right)$ and livestock compost $(\mathrm{HV}+$ compost), and a no-HV/no-compost treatment (bare). Total organic $\mathrm{N}$ applied as $\mathrm{HV}$, $\mathrm{HV}+$ compost, and compost was similar and depended on HV biomass obtained in the HV plots each year. The livestock compost was made from a mixture of cattle slurry with grass residues. All plots received a supple- mental $\mathrm{N}$ fertilizer at a rate of $100 \mathrm{~kg} \mathrm{~N} / \mathrm{ha}$ as LPS100 (41N; JCAM AGRI. Co., Ltd., Tokyo, Japan) (30-d delayed $\mathrm{N}$ release in soil at $25^{\circ} \mathrm{C}$, and then 70 -d release of $80 \%$ of its total $\mathrm{N}$ following a sigmoidal pattern). This $\mathrm{N}$ fertilizer amount is equivalent to $33 \%$ to $50 \%$ of the recommended $\mathrm{N}$ fertilizer amount for fresh-market tomato production across different regions in Japan. The treatments were arranged in a randomized complete block design with three replicates. The plot area was $2.4 \mathrm{~m}^{2}(3 \times 0.8 \mathrm{~m})$ for both years. Each plot contained 12 plants in double lines spaced $0.5 \mathrm{~m}$ between plants and $0.5 \mathrm{~m}$ between lines. Only eight plants in the core site were tested; the other four plants were considered borders. The distance from the center to the center between beds was $1.5 \mathrm{~m}$ for both years, resulting in a planting density of 26,667 plants/ha.

Tomato seedlings production. Rootstock cultivar Friendship was sown in a plastic high tunnel in 128-cell flats (cell size, $3 \times 3 \times 4 \mathrm{~cm}$ ) on 11 Mar., whereas fresh-market cultivar
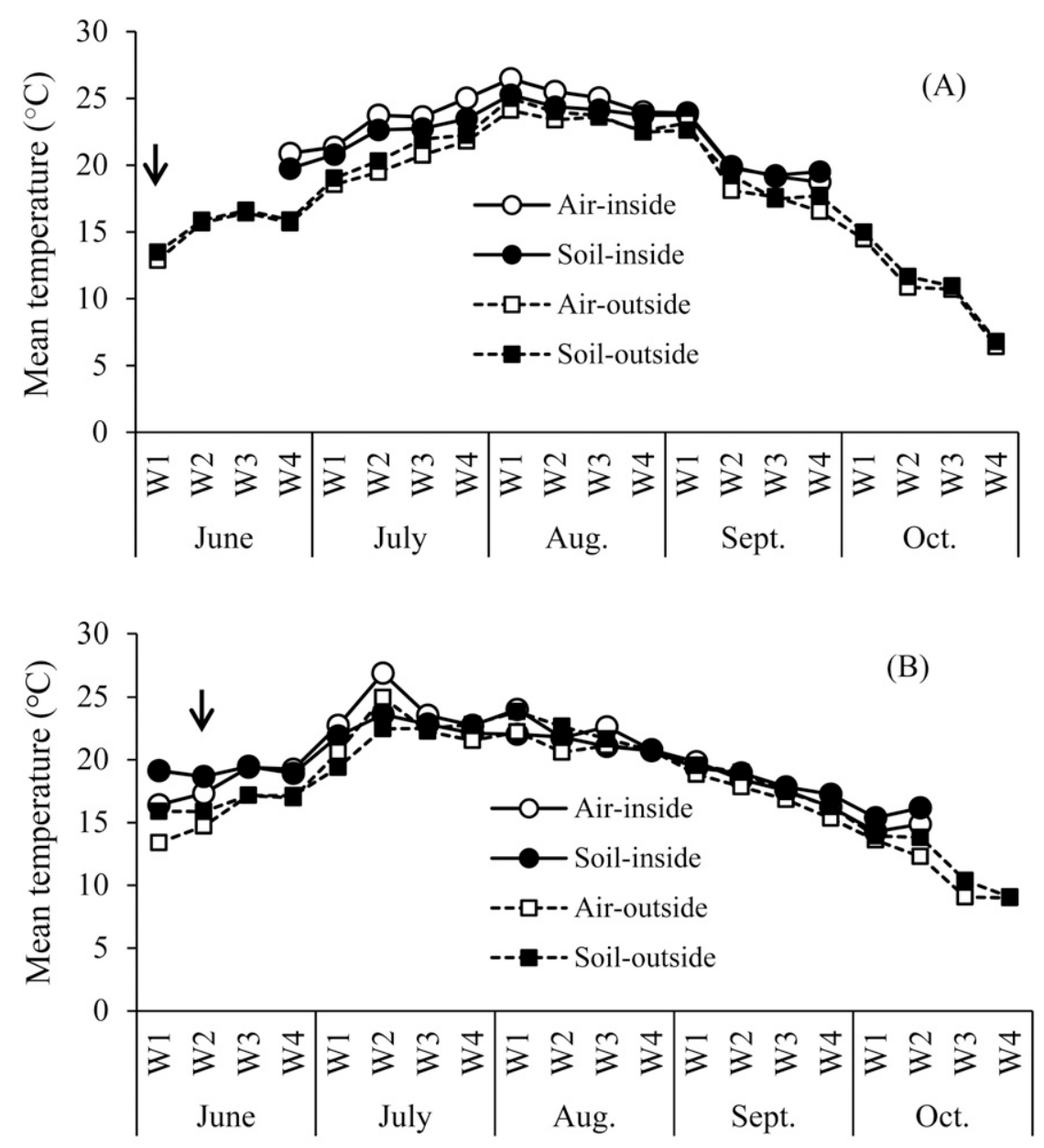

Period of mesurement (weeks and months)

Fig. 1. Mean soil and air temperatures (inside and outside the plastic high tunnel) measured during the period of tomato cultivation in (A) 2016 and (B) 2017. The air and soil temperatures in the plastic high tunnel were measured from 22 June to 30 Sept. 2016 and from 1 June to 11 Oct. 2017. The outside soil and air temperatures were measured from 1 June to 30 Oct. in both years. The soil and air temperatures (inside and outside the plastic high tunnel) were measured at a soil depth of $10 \mathrm{~cm}$ and a height of $1.5 \mathrm{~m}$, respectively. Arrows indicate the tomato transplanting date.

Reika was sown in flat plastic boxes $(43 \times 33 \times$ $7 \mathrm{~cm}$ ) on 15 Mar., and grafted on $18 \mathrm{Apr}$. 2016 using a tube grafting method. Three weeks after grafting, seedlings were transferred into plastic pots with a diameter of 12 $\mathrm{cm}$, where they grew until the emergence of the first flower cluster. In 2017, 'Reika' seedlings were planted in flat plastic boxes on 20 Apr. and were transferred to plastic pots 3 weeks later. Nongrafted seedlings were used for transplanting.

Field preparation. Before tillage, soil samples were taken in 2015 for analysis of the initial soil chemical composition. The soil was tilled by rotary cultivator in fall, and beds $0.15 \mathrm{~m}$ high and $0.8 \mathrm{~m}$ wide were raised. HV 'Kantaro' (winter-hardy cultivar; Snow Brand Seed Co., Ltd., Hokkaido, Japan) was planted on 2 Oct. 2015 and 4 Oct. 2016, although the HV planted in 2016 did not survive under a long period of snow cover and a second planting was necessary. Thus, the soil was left to dry after the snow melted and was tilled in late May. Beds were raised soon thereafter. HV 'Mamesuke' (nonwinterhardy cultivar; Snow Brand Seed Co., Ltd.) was planted on 25 Mar. 2017 at the same seeding rates used for 'Kantaro'. No fertilizer or agrochemicals were applied to cover crops to supply additional nutrients or to control weeds and pests. Water was applied by an irrigation tube as needed after snowmelt in 2016 and just after planting HV in 2017. Cover crops were ended at the flowering stage by cutting the plants by hand 2 to 5 $\mathrm{cm}$ above the ground on 28 May 2016 and 13 June 2017. HV residues were chopped in small pieces $(\approx 10 \mathrm{~cm})$ and incorporated into the soil with or without compost (soil depth, $15-20 \mathrm{~cm}) 2$ to $3 \mathrm{~d}$ before tomato transplanting. All fertilizers were incorporated in conjunction with $\mathrm{HV}$ or compost residues. $\mathrm{P}$ and $\mathrm{K}$ fertilizers were applied as fused $\mathrm{Mg}$, $\mathrm{Ca}$, and phosphate $(9 \mathrm{P}-36 \mathrm{Ca}-9 \mathrm{Mg})$; and as potassium sulfate $(42 \mathrm{~K}-17 \mathrm{~S})$ at a rate of 200 $\mathrm{kg} \cdot \mathrm{ha}^{-1}$ each, respectively.

Tomato cultivation. Two and half-monthold tomato seedlings were transplanted in plots by hand on 1 June 2016 and on 15 June 2017. After transplanting, an irrigation system was installed to water tomatoes two to three times a week until the last harvest each year. For trellising tomato plants, a hangingstring system was established just after transplanting. Lateral shoots were removed as they appeared to allow only the main shoot to grow. Fruit was collected from the first to the eighth cluster, and only four fruit were allowed to set in each cluster. Pesticides were applied three times to control or prevent thrips, fruit worms, and leaf diseases. Weeds were removed by hand.

$H V$ and tomato biomass, and $C$ and $N$ contents. Aboveground fresh-weight (FW) biomass yield of $\mathrm{HV}$ was determined using all the residues obtained in a plot $\left(2.4 \mathrm{~m}^{2}\right)$. Samples were taken and dried in an oven at $60{ }^{\circ} \mathrm{C}$ until constant weight to determine dry weight (DW), and then $\mathrm{C}$ and $\mathrm{N}$ contents. In Oct. 2017, after the last harvest, tomato plants in each plot were cut 2 to $3 \mathrm{~cm}$ above 
the ground and were taken for measurement of FW. Three samples were taken in each treatment and were oven-dried to determine DW. For analysis of $\mathrm{C}$ and $\mathrm{N}$ contents, tomato plants were divided into two parts: stems and leaves. In each treatment, 18 redripe tomato fruit were collected three times during the harvest events, oven-dried, and mixed thoroughly, and then a subsample was taken for analysis. Tomato stems, leaves, and fruit subsamples were ground with a vibrating sample mill (TI-100; CMT Co., Ltd, Tokyo, Japan) before analysis. Total $\mathrm{C}$ and $\mathrm{N}$ contents of $\mathrm{HV}$, tomato shoots, and fruit were determined by combustion at $950{ }^{\circ} \mathrm{C}$ using an elemental analyzer (Vario EL III; Elementar, Hanau, Germany).

Soil $C$ and $N$ contents, and bulk density. Soil samples for inorganic $\mathrm{N}\left(\mathrm{NO}_{3}{ }^{-} \mathrm{N}+\right.$ $\mathrm{NH}_{4}{ }^{+}-\mathrm{N}$ ) were collected every 2 weeks from 2 to 16 weeks after transplanting (WAT) in 2016 and 2017. Soil samples were taken from five sites in each plot at a 0 to $10-\mathrm{cm}$ depth and were mixed thoroughly to make a composite sample for each treatment. Soil samples were dried at room temperature and sieved with 2-mm mesh, then stored in a cool chamber at $4{ }^{\circ} \mathrm{C}$ until undergoing analysis of $\mathrm{NO}_{3}{ }^{-} \mathrm{N}$ and $\mathrm{NH}_{4}{ }^{+}-\mathrm{N}$ by means of a soil analyzer (ZA-II; Fujihira Co., Ltd., Tokyo, Japan). $\mathrm{NO}_{3}{ }^{-}-\mathrm{N}$ was determined following the alkali reduction-diazotization method and $\mathrm{NH}_{4}{ }^{+}-\mathrm{N}$ was determined by a modified indophenol method. Soil samples for total C and $\mathrm{N}$ analysis were collected after the last tomato harvest in each year and treated as described earlier for inorganic N. Soil total C and $\mathrm{N}$ were determined by combustion at $950{ }^{\circ} \mathrm{C}$ by means of an elemental analyzer (Vario EL III; Elementar). Briefly, $20 \mathrm{mg}$ of milled dry soil was weighed in Sn foil capsules and then analyzed.

To determine bulk density, intact soil cores were collected before soil cultivation in 2015 and after the last tomato harvest in 2016 and 2017 by a hand-pressing sampler that contained a steel volumetric ring (100 $\mathrm{cm}^{3}$ ) at depth of 0 to $10 \mathrm{~cm}$. Three core samples were taken from each plot. Soil samples from each ring were transferred to a paper bag and dried in an oven at $105{ }^{\circ} \mathrm{C}$ until constant weight, and their DW was then recorded. Bulk density was determined as the ratio of DW soil contained in a ring per its volume. Soil $\mathrm{C}$ and $\mathrm{N}$ stocks were calculated using the following equation: Soil $\mathrm{C} / \mathrm{N}$ stocks $\left(\mathrm{t} \cdot \mathrm{ha}^{-1}\right)=Y / 100 \times B D \times d \times 10^{4} \mathrm{~m}^{2} \cdot \mathrm{ha}^{-1}$, where $Y$ is the soil C or N content, $B D$ is bulk density (measured in megagrams per cubic meter), and $d$ is soil thickness (measured in meters). The baseline soil $\mathrm{C}$ and $\mathrm{N}$ stocks determined in 2015 were $33.7 \mathrm{t} \cdot \mathrm{ha}^{-1}$ and $2.25 \mathrm{t} \cdot \mathrm{ha}^{-1}$, respectively.

Nitrate concentration in leaf petiole sap. To monitor the plant response to soil $\mathrm{N}$ availability during the tomato growing period, the nitrate concentration in the leaf petiole just below the first cluster was determined by means of a reflection photometer (RQ flex; Merk Co., Ltd., Darmstadt, Germany) (Sakaguchi et al., 2004). One gram of petioles was macerated with $49 \mathrm{~mL}$ deionized water in 2016 or with $19 \mathrm{~mL}$ deionized water in 2017. The leaf petiole samples were collected and rinsed with deionized water and analyzed immediately at 2, 4, 6, and 10 WAT in 2016; and at 4, 6, 8, and 10 WAT in 2017.

Nitrogen uptake. $\mathrm{N}$ uptake was calculated as follows: Nup $\left(\mathrm{kg} \cdot \mathrm{ha}^{-1}\right)=a Y+b Z$, where $a$ is the $\mathrm{N}$ content of the shoot (average $\mathrm{N}$ content of stem and leaves), $Y$ is the total DW biomass of the shoot in each treatment, $b$ is the $\mathrm{N}$ content of tomato fruit, and $Z$ is the total DW of fruit (marketable and unmarketable) for each treatment. $\mathrm{N}$ recovery from $\mathrm{HV}$ and compost residues was calculated as follows: $\mathrm{N}$ recovery $(\%)=\left\{\left[\mathrm{Nup}_{(\mathrm{HV}, \text { Compost, } \mathrm{HV}+\text { compost })}-\right.\right.$ $\left.\mathrm{Nup}_{(\text {Bare })}\right] / \mathrm{N}$ input $\} \times 100$.

Tomato yield. Red-ripe fruit was collected from eight test plants in each plot from 22 July to 28 Sept. 2016, and from 9 Aug. to 9 Oct. 2017. Harvested fruit was classified in two categories: marketable (FW $\geq 100 \mathrm{~g}$ with no physiologic disorders) and unmarketable (FW $<100 \mathrm{~g}$ and/or with physiologic disorders such as misshapen fruit, blossom end rot, black spots, and huge scars). Tomato yield (measured in tons per hectare) was calculated by multiplying the total fruit weight of one plant by plant density $(26,667$ plants/ha).

Statistical analyses. The significance of mean differences among treatments was tested using analysis of variance and Tukey's honestly significant difference test with $\mathrm{R}$ software (R Core Team, 2014). The $t$ test was used to evaluate the significance of mean differences between the 2 years when the year and/or the treatment $\times$ year interaction were significant. Statistical significance was evaluated at $P \leq 0.05$, unless otherwise stated.

\section{Results}

HV biomass yield, compost application, and $C$ and $N$ inputs. In 2016, the DW HV biomass produced in the $\mathrm{HV}$ and $\mathrm{HV}+$ compost plots was similar, but only 2460 $\mathrm{kg} \cdot \mathrm{ha}^{-1}$ was incorporated in the $\mathrm{HV}+\mathrm{com}-$ post plots (Table 1). However, in 2017, the HV biomass produced in the HV plots was greater than that produced in the $\mathrm{HV}+$ compost plots, so all HV residues obtained in the HV + compost treatment were incorporated into the soil. The $\mathrm{N}$ content of HV 'Kantaro' and 'Mamesuke' was similar and greater than that of livestock compost. The quantity of compost applied in the compost plots was equivalent to the total organic $\mathrm{N}$ applied in the HV plots, whereas the $\mathrm{HV}+$ compost plots received about half the amount of that applied in the compost plots. The total organic $\mathrm{N}$ applied in the HV, $\mathrm{HV}+$ compost, and compost plots was similar, but the quantity of organic $\mathrm{C}$ applied to the soil differed slightly, with a significant variation among the treatments in 2016 than in 2017. The HV C:N ratios were 10.3 in 2016 and 10.9 in 2017, whereas the compost $\mathrm{C}: \mathrm{N}$ ratio was 11 .
Soil inorganic $N$, and nitrate concentration in leaf petiole sap. The effect of hairy vetch and compost on soil inorganic N (SIN) was significant for all sampling dates for both years (Fig. 2). In 2016, HV displayed the greatest SIN levels $(89.6 \mathrm{mg} \mathrm{N} / \mathrm{kg})$ at $2 \mathrm{WAT}$, followed by $\mathrm{HV}+$ compost (40.1 $\mathrm{mg} \mathrm{N} / \mathrm{kg}$ ), whereas the compost and bare treatments showed similar and lower SIN levels (26.4 and $23.8 \mathrm{mg} \mathrm{N} / \mathrm{kg}$, respectively). A decreasing trend was observed after 2 WAT for the $\mathrm{HV}$ and the HV + compost treatments; however, the HV treatment generally showed greater SIN levels throughout the measurement period than the other treatments. The SIN levels in compost plots increased from 2 to 8 WAT, reaching its greatest level $(54 \mathrm{mg}$ $\mathrm{N} / \mathrm{kg}$ ), but tended to decrease thereafter. The bare treatment showed the up-and-down pattern, but in general its SIN levels were less than those of the other treatments, except at 10 and 14 WAT. In 2017, all treatments displayed the greatest SIN levels at 2 WAT and then tended to decrease. As in 2016, the HV treatment showed greater SIN levels compared with other treatments during the examination period except at $10 \mathrm{WAT}$, when its SIN levels were the least. In contrast, the bare treatment showed lower SIN levels compared with other treatments, except at 10 WAT, when its SIN levels were even greater than those of the HV treatment.

The incorporation of $\mathrm{HV}$ and compost residues influenced significantly the nitrate levels in the leaf petioles in both years (Table 2). The HV treatment displayed the greatest nitrate levels, especially at 2 to 6 WAT in 2016 and 4 to 8 WAT in 2017. The $\mathrm{HV}+$ compost treatment showed greater nitrate levels than the bare and compost treatments at 2 to 4 WAT in 2016 and 4 to 6 WAT in 2017, but after those periods its nitrate levels were similar or less than those of the bare and compost treatments. The nitrate levels in the compost and bare treatments were generally less than the HV treatment during the entire measurement period. In 2017, the nitrate levels in the leaf petiole in the bare treatment at 4 WAT were even less than $100 \mathrm{mg} \cdot \mathrm{L}^{-1}$ (the detection limit). Averaged across sampling dates, the $\mathrm{HV}$ treatment displayed the greatest nitrate levels in both years, followed by the HV + compost treatment; the compost and bare treatments displayed the lowest levels, especially the bare treatment.

Soil $C$ and $N$ stocks. Soil $\mathrm{C}$ stock was influenced significantly by the addition of $\mathrm{HV}$ and compost residues to the soil in 2016 and 2017 (Table 3). The treatment $\times$ year interaction and the year effect were significant (Table 4). In 2016, soil C stock was greater in the $\mathrm{HV}$, compost, and $\mathrm{HV}+$ compost treatments than in the bare treatment. In 2017, the HV, compost, and bare treatments showed greater soil $\mathrm{C}$ stock than the $\mathrm{HV}+$ compost treatment. However, averaged across years, all $\mathrm{HV}$ and compost treatments displayed greater soil $\mathrm{C}$ stock than the bare treatment. The soil $\mathrm{C}$ stock in the $\mathrm{HV}+$ compost plots decreased from 2016 to 
Table 1. Hairy vetch and compost biomass, carbon and nitrogen applied to the soil in 2016 and 2017.

\begin{tabular}{|c|c|c|c|c|c|c|c|c|c|c|}
\hline \multirow[b]{2}{*}{$\mathrm{Yr}$} & \multirow[b]{2}{*}{ Treatments ${ }^{\mathrm{z}}$} & \multicolumn{4}{|c|}{ Hairy vetch } & \multicolumn{3}{|c|}{ Compost } & \multirow[b]{2}{*}{$\begin{array}{c}\text { Total N applied } \\
\left(\mathrm{kg} \cdot \mathrm{ha}^{-1}\right)\end{array}$} & \multirow[b]{2}{*}{$\begin{array}{c}\text { Total C applied } \\
\left(\mathrm{kg} \cdot \mathrm{ha}^{-1}\right)\end{array}$} \\
\hline & & $\begin{array}{c}\text { Seeding rate } \\
\left(\mathrm{kg} \cdot \mathrm{ha}^{-1}\right)\end{array}$ & $\begin{array}{c}\text { Dry wt } \\
\left(\mathrm{kg} \cdot \mathrm{ha}^{-1}\right)\end{array}$ & $\begin{array}{c}\mathrm{N} \text { content } \\
(\%)\end{array}$ & $\begin{array}{c}\text { N applied } \\
\left(\mathrm{kg} \cdot \mathrm{ha}^{-1}\right)\end{array}$ & $\begin{array}{l}\text { Dry wt } \\
\left(\mathrm{kg} \cdot \mathrm{ha}^{-1}\right)\end{array}$ & $\begin{array}{l}\text { N content } \\
(\%)\end{array}$ & $\begin{array}{c}\mathrm{N} \text { applied } \\
\left(\mathrm{kg} \cdot \mathrm{ha}^{-1}\right)\end{array}$ & & \\
\hline \multirow[t]{3}{*}{$\overline{2016}$} & $\mathrm{HV}$ & 20 & 4,919 & 4.02 & 198 & - & - & - & 198 & 2,032 \\
\hline & $\mathrm{HV}+$ compost & 10 & $2,460^{y}$ & 4.02 & 98.9 & 3,146 & 3.15 & 99.1 & 198 & 2,110 \\
\hline & Compost & - & - & - & - & 6,280 & 3.15 & 198 & 198 & 2,184 \\
\hline \multirow[t]{3}{*}{2017} & $\mathrm{HV}$ & 20 & 4,683 & 3.99 & 187 & - & - & - & 187 & 2,042 \\
\hline & $\mathrm{HV}+$ compost & 10 & 2,898 & 3.99 & 116 & 2,254 & 3.15 & 71.0 & 187 & 2,048 \\
\hline & Compost & - & - & - & - & 5,937 & 3.15 & 187 & 187 & 2,065 \\
\hline
\end{tabular}

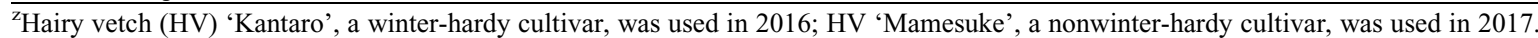

${ }^{\mathrm{y}}$ Represents about half of the dry weight biomass obtained in HV plots, whereas the total dry weight biomass yield obtained in $\mathrm{HV}+\mathrm{compost}$ was $4154 \mathrm{~kg} \cdot \mathrm{ha}^{-1}$.
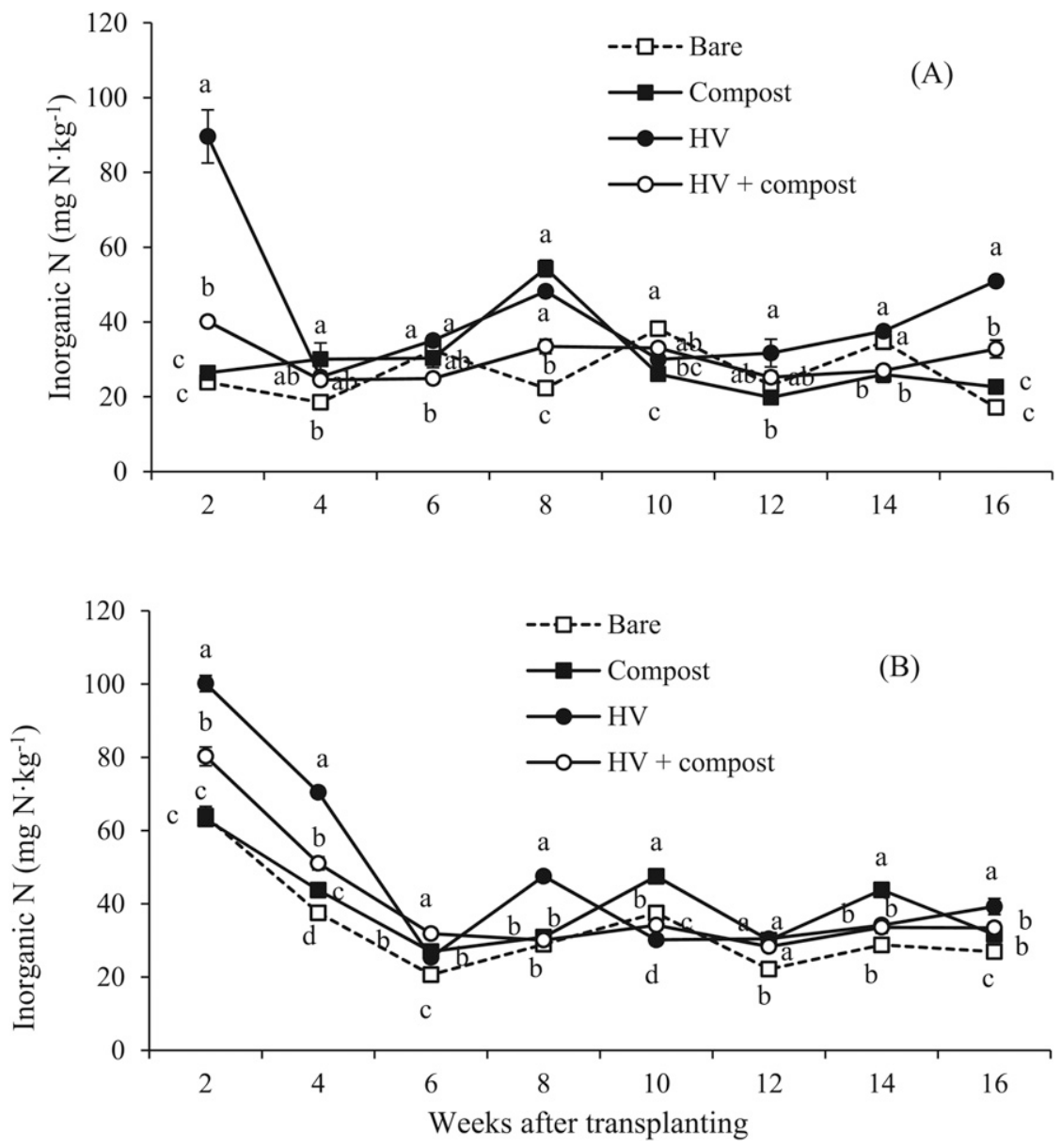

Fig. 2. Soil inorganic N levels during the period of tomato cultivation in (A) 2016 and (B) 2017. Vertical bars represent SE $(n=3)$. Means followed by the same letters in each week are not significantly different at $5 \%$ by Tukey's honestly significant difference test. $\mathrm{HV}=$ hairy vetch.

2017. Averaged across treatments, soil C stock was greater in 2016 than 2017. The effect of $\mathrm{HV}$ and compost on soil $\mathrm{N}$ stock was only significant in 2016 (Table 3). The treatment $x$ year interaction and year effect were significant (Table 4). The compost and $\mathrm{HV}+$ compost treatments displayed greater soil $\mathrm{N}$ stocks than the HV and bare treatments in 2016. However, averaged across years, soil N stock was greater in the compost and HV treatments than in the $\mathrm{HV}+$ compost and bare treatments. Soil $\mathrm{N}$ stock in the HV, HV + compost, and bare treatments increased from 2016 to 2017 . Averaged across treatments, soil $\mathrm{N}$ stock was greater in 2017 than 2016.

Tomato yield and average fruit $F W$. The effects of HV and compost on marketable and total yields were significant in 2016 and 2017 (Table 5). Likewise, the treatment $\times$ year interaction was significant for both yields, but the year effect was significant for marketable yield only (Table 4). In 2016, the marketable and total yields were greater in the HV and $\mathrm{HV}+$ compost treatments, followed by the compost treatment, and was the lowest in the bare treatment. In 2017, the compost treatment exhibited the greatest marketable yield, followed by the HV and $\mathrm{HV}+$ compost treatments. All HV and compost treatments exhibited similar and greater total yield than the bare treatment. Marketable and total yields increased from 2016 to 2017 in the compost treatment, whereas the total yield decreased from 2016 to 2017 in the HV treatment. Averaged across treatments, marketable yield increased from 2016 to 2017. The treatment effect on unmarketable yield was significant in 2016 only (Table 5). The treatment $\times$ year interaction and year effect were significant (Table 4). The unmarketable yield was greater in the compost and $\mathrm{HV}$ treatments than in the bare and HV + compost treatments. All treatments showed a greater unmarketable yield in 2016 than in 2017. Averaged across treatments, unmarketable yield decreased from 2016 to 2017. With regard to the average marketable fruit weight, the HV, HV + compost, and compost treatments increased the fruit weight significantly compared with the bare treatment in 2016.

Tomato shoot biomass, $N$ uptake, and $N$ recovery. Tomato shoot biomass and $\mathrm{N}$ uptake differed greatly among treatments (Table 6). Shoot biomass (DW) was greater in the HV treatment, followed by the HV + compost and compost treatments, and was least in the bare treatment. Likewise, the HV, compost, and $\mathrm{HV}+$ compost treatments displayed greater shoot and fruit $\mathrm{N}$ uptake. As a result, the total $\mathrm{N}$ uptake was greater in the $\mathrm{HV}, \mathrm{HV}+$ compost, and compost treatments than in the bare treatment. The HV treatment showed the greatest total $\mathrm{N}$ uptake. The $\mathrm{N}$ recovered by tomatoes in the HV treatment was greater than that in the compost and $\mathrm{HV}+$ compost treatments, which was similar.

\section{Discussion}

$H V$ biomass yield, compost application, and $C$ and $N$ contents. The HV 'Kantaro' (a winter-hardy type) grew and accumulated large biomass for a period of about 7 months, whereas the HV vetch 'Mamesuke' (a nonwinter-hardy type) grew for only about 2.5 months. However, despite the difference in the extent of the growing periods, the biomass yield of the two HV types and their respective $\mathrm{C}$ and $\mathrm{N}$ contents were similar (Table 1). 'Mamesuke' has the ability to accumulate large biomass in a short growing period, as shown in our previous study (Muchanga et al., 2017); however, the biomass of 'Kantaro' was less than expected as a result of decreased planting density because some plants died under a long period of snow cover. HV plants were covered completely with snow from late Nov. 2015 to early Mar. 2016. The snowpack thickness ranged from about $0.3 \mathrm{~m}$ in Nov. 2015 to about $1 \mathrm{~m}$ in Jan. 2016. The C:N ratios of $\mathrm{HV}$ and livestock 
Table 2. Nitrate concentration in the leaf petiole sap just below the first cluster during the period of tomato cultivation in 2016 and 2017.

\begin{tabular}{|c|c|c|c|c|c|c|c|c|c|c|}
\hline \multirow{2}{*}{ Treatments ${ }^{z}$} & \multicolumn{5}{|c|}{2016} & \multicolumn{5}{|c|}{2017} \\
\hline & \multicolumn{4}{|c|}{ Weeks after transplanting $\left(\mathrm{mg} \cdot \mathrm{L}^{-1}\right)$} & Mean & \multicolumn{4}{|c|}{ Weeks after transplanting $\left(\mathrm{mg} \cdot \mathrm{L}^{-1}\right)$} & Mean \\
\hline Bare & $250 \mathrm{~d}^{\mathrm{y}}$ & $467 \mathrm{~b}$ & $367 \mathrm{~b}$ & $707 \mathrm{~b}$ & $448 \mathrm{~d}$ & $\mathrm{LO}^{\mathrm{x}}$ & $460 \mathrm{c}$ & $527 \mathrm{~b}$ & $473 \mathrm{~b}$ & $365 c$ \\
\hline $\mathrm{HV}$ & $3,900 \mathrm{a}$ & $3,750 \mathrm{a}$ & $2,227 \mathrm{a}$ & $967 \mathrm{a}$ & $2,711 \mathrm{a}$ & $2,627 \mathrm{a}$ & $2,667 \mathrm{a}$ & $2,640 \mathrm{a}$ & $767 \mathrm{a}$ & $2,175 \mathrm{a}$ \\
\hline $\mathrm{HV}+$ compost & $2,833 \mathrm{~b}$ & $3,700 \mathrm{a}$ & $333 \mathrm{~b}$ & $580 \mathrm{c}$ & $1,874 \mathrm{~b}$ & $1,853 \mathrm{~b}$ & $1,593 \mathrm{~b}$ & $827 \mathrm{~b}$ & $487 \mathrm{~b}$ & $1,190 \mathrm{~b}$ \\
\hline
\end{tabular}

${ }^{\mathrm{z}}$ Bare, plots with no HV and compost; Compost, plots with livestock compost; HV, plots incorporating HV planted at a seeding rate of $20 \mathrm{~kg} \cdot \mathrm{ha}^{-1} ; \mathrm{HV}+\mathrm{compost}$ plots incorporating HV planted at a seeding rate of $10 \mathrm{~kg} \cdot \mathrm{ha}^{-1}$ and livestock compost. All plots received $100 \mathrm{~kg} \mathrm{~N} / \mathrm{ha}$ as controlled-release N fertilizer, LPS100. ${ }^{\mathrm{y}}$ Means followed by the same letters in each column are not significantly different at $5 \%$ by Tukey's honestly significant difference test.

${ }^{\mathrm{x}}$ Nitrate concentration below the detection limit.

$\mathrm{HV}=$ hairy vetch.

Table 3. Soil C and N stocks after tomato cultivation at a 0- to 10-cm soil depth in 2016 and 2017.

\begin{tabular}{|c|c|c|c|c|c|c|}
\hline \multirow[b]{2}{*}{ Treatments } & \multicolumn{3}{|c|}{$\mathrm{C}\left(\mathrm{t} \cdot \mathrm{ha}^{-1}\right)$} & \multicolumn{3}{|c|}{$\mathrm{N}\left(\mathrm{t} \cdot \mathrm{ha}^{-1}\right)$} \\
\hline & 2016 & 2017 & $\overline{\text { Mean }}$ & 2016 & 2017 & Mean \\
\hline Compost & $35.7 \mathrm{a}$ & $33.7 \mathrm{a}$ & $34.7 \mathrm{a}$ & $2.81 \mathrm{a}$ & 2.86 & $2.84 \mathrm{a}$ \\
\hline Mean & $35.0 \mathrm{~A}$ & $33.7 \mathrm{~B}$ & & $2.48 \mathrm{~B}$ & $2.79 \mathrm{~A}$ & \\
\hline Significance & & & $\dagger$ & & NS & \\
\hline
\end{tabular}

${ }^{\mathrm{z}}$ Means followed by the same letters are not significantly different at $5 \%$ or $10 \%$ by Tukey's honestly significant difference test for treatments (columns, lowercase letters) and the $t$ test for years, within and across treatments (rows, uppercase letters).

${ }^{\mathrm{Ns},}{ }^{\dagger}$ Nonsignificant or significant at $P \leq 0.1$, respectively.

$\mathrm{HV}=$ hairy vetch

Table 4. Significance of the year and treatment $\times$ year interaction for soil $\mathrm{C}$ and $\mathrm{N}$ stocks, tomato yield, and average fruit weight.

\begin{tabular}{lllccc}
\hline & & \multicolumn{3}{c}{ Tomato yield } \\
\cline { 4 - 6 } Source & Soil C stock & Soil N stock & Marketable & Unmarketable & Total \\
\hline Year & $0.00120^{* *}$ & $0.000002^{* * *}$ & $0.000009^{* * *}$ & $<0.000001^{* * *}$ & $0.8392 \mathrm{NS}$ \\
Treatment $\times$ year & $0.00007^{* * *}$ & $0.007166^{* *}$ & $0.003320^{* *}$ & $0.000676^{* * *}$ & $0.113646 \mathrm{NS}$ \\
\hline
\end{tabular}

Ns, ${ }^{*}, * *, * * *$ Nonsignificant or significant at $P \leq 0.05,0.01$, or 0.001 , respectively.

Table 5. Effects of hairy vetch (HV) and livestock compost on tomato yield and average fruit weight in 2016 and 2017.

\begin{tabular}{|c|c|c|c|c|c|c|c|c|}
\hline \multirow[b]{3}{*}{ Treatments } & \multicolumn{4}{|c|}{2016} & \multicolumn{4}{|c|}{2017} \\
\hline & \multicolumn{3}{|c|}{ Yield $\left(\mathrm{t} \cdot \mathrm{ha}^{-1}\right)$} & \multirow{2}{*}{$\begin{array}{c}\text { Avg fruit } \\
\text { wt }(\mathrm{g})^{\mathrm{z}}\end{array}$} & \multicolumn{3}{|c|}{ Yield $\left(\mathrm{t} \cdot \mathrm{ha}^{-1}\right)$} & \multirow{2}{*}{$\begin{array}{c}\text { Avg fruit } \\
\text { wt (g) }\end{array}$} \\
\hline & Marketable & Unmarketable & Total & & Marketable & Unmarketable & Total & \\
\hline$\overline{\text { Bare }}$ & $85.9 \mathrm{c}^{\mathrm{y}}$ & $14.3 \mathrm{bB}$ & $100 \mathrm{~b}$ & $193 \mathrm{c}$ & $98.8 \mathrm{c}$ & $6.42 \mathrm{~A}$ & $105 \mathrm{~b}$ & 190 \\
\hline Compost & $91.7 \mathrm{bcB}$ & $20.5 \mathrm{aB}$ & $112 \mathrm{abB}$ & $222 \mathrm{bc}$ & $112 \mathrm{aA}$ & $6.02 \mathrm{~A}$ & $118 \mathrm{aA}$ & 226 \\
\hline $\mathrm{HV}$ & $105 \mathrm{a}$ & $17.8 \mathrm{abB}$ & $123 \mathrm{aA}$ & $253 \mathrm{a}$ & $108 \mathrm{ab}$ & $5.79 \mathrm{~A}$ & $114 \mathrm{aB}$ & 232 \\
\hline $\mathrm{HV}+$ compost & $102 a b$ & $14.7 \mathrm{bB}$ & $117 \mathrm{a}$ & $243 \mathrm{ab}$ & $106 \mathrm{~b}$ & $7.22 \mathrm{~A}$ & $113 \mathrm{a}$ & 220 \\
\hline Mean & $96.2 \mathrm{~B}$ & $16.8 \mathrm{~A}$ & 113 & 228 & $106 \mathrm{~A}$ & $6.36 \mathrm{~B}$ & 112 & 217 \\
\hline Significance & & & & & & NS & & NS \\
\hline
\end{tabular}

${ }^{\mathrm{z}}$ Average fruit weight of marketable fruits.

${ }^{\mathrm{y}}$ Means followed by the same letters are not significantly different at 5\% by Tukey's honestly significant difference test for treatments (columns, lowercase letters) and the $t$ test for years, within and across treatments in each yield category (rows, uppercase letters).

Ns Nonsignificant.

Table 6. Effects of hairy vetch (HV) and livestock compost on tomato shoot biomass, $\mathrm{N}$ uptake, and $\mathrm{N}$ recovery in 2017.

\begin{tabular}{|c|c|c|c|c|c|}
\hline \multirow[b]{2}{*}{ Treatment } & \multirow[b]{2}{*}{ Shoot biomass $\left(\mathrm{kg} \cdot \mathrm{ha}^{-1}\right)$} & \multicolumn{3}{|c|}{$\mathrm{N}$ uptake $\left(\mathrm{kg} \cdot \mathrm{ha}^{-1}\right)$} & \multirow[b]{2}{*}{$\mathrm{N}$ recovery $(\%)$} \\
\hline & & Shoot & Fruit & Total & \\
\hline Bare & $4,586 \mathrm{c}^{\mathrm{z}}$ & $73.7 \mathrm{c}$ & $85.5 \mathrm{c}$ & $159 \mathrm{c}$ & - \\
\hline Compost & $5,572 \mathrm{~b}$ & $89.3 \mathrm{~b}$ & $98.9 \mathrm{~b}$ & $188 \mathrm{~b}$ & 15.5 \\
\hline $\mathrm{HV}$ & $6,812 \mathrm{a}$ & $109 \mathrm{a}$ & $111 \mathrm{a}$ & $220 \mathrm{a}$ & 32.6 \\
\hline $\mathrm{HV}+$ compost & $6,072 \mathrm{~b}$ & $92.1 \mathrm{~b}$ & $95.2 \mathrm{~b}$ & $187 \mathrm{~b}$ & 15.0 \\
\hline
\end{tabular}

${ }^{\mathrm{z}}$ Means followed by the same letters in each column are not significantly different at 5\% by Tukey's honestly significant difference test.

compost were less than 20 , suggesting a rapid decomposition of the residues after incorporation into the soil (Brady and Weil, 2007), although their decomposition speed may have differed because the composition of $\mathrm{C}$ and $\mathrm{N}$ in manure or compost is much more important than the general C: $\mathrm{N}$ ratio (Eghball et al., 2002).

SIN and nitrate concentration in leaf petiole. Incorporation of large amounts of $\mathrm{HV}$ residues in the soil influenced soil $\mathrm{N}$ availability (Kuo et al., 2001). HV plots showed greater SIN levels for a longer period of tomato cultivation than other treatments, especially at 2 WAT in both years. The rapid decrease in SIN levels after 2 WAT was probably a result of an increase in $\mathrm{N}$ uptake by the growing tomatoes. Increased SIN 
levels during the early period in HV plots were a result of rapid decomposition of its residues after incorporation because of a high $\mathrm{N}$ concentration and a low C:N ratio. Similar results have been reported in previous studies. Sainju et al. (2000) reported increased SIN levels in May 1996 and 1997, 15 to $30 \mathrm{~d}$ after the incorporation of HV residues in the soil. Likewise, Sugihara et al. (2013) reported that most of the $\mathrm{N}$ derived from $\mathrm{HV}$ residues was absorbed by tomato plants by 4 WAT. However, we observed an increasing trend during the late period, especially in 2016, possibly because of decomposition of the HV residues that were initially resistant to microbial degradation (e.g., roots) and/or decomposition of residues that were not initially well incorporated. These observations point out that hairy vetch contribution to soil $\mathrm{N}$ pools may last for a long time. Application of manure or composted manure can result in increased concentrations of nutrients and organic matter in the soil (Eghball et al., 2004; Kong et al., 2005). Compost is considered a slow-release organic fertilizer, so its influence on SIN was not as great as that of HV. Averaged across sampling dates, in 2016, SIN levels increased by $65.4 \%$, $14.4 \%$, and $12.2 \%$ in the HV, HV + compost, and compost treatments, respectively; whereas in 2017, the HV, HV + compost, and compost treatments increased SIN levels by $41.7 \%, 21.2 \%$, and $19.3 \%$, respectively, compared with the bare treatment. Despite the reduced $\mathrm{N}$ input in 2017 compared with 2016, the influence of the compost and HV + compost treatments on SIN increased from 2016 to 2017 , possibly as a result of the residual effect of compost residues. The residual effects of manure or compost application on crop production and soil properties can last for several years because only a fraction of $\mathrm{N}$ and other nutrients in manure or compost become plant available during the first year after application (Eghball et al., 2004; Wallingford et al., 1975). Therefore, significant amounts of $\mathrm{N}$ applied to the soil as compost in 2016 may have remained in the soil and counted toward the following year. The greater SIN levels in the bare treatment at 2 WAT compared with other sampling dates in 2017 were probably a result of soil $\mathrm{N}$ contribution because the controlled-release $\mathrm{N}$ fertilizer applied to it has a lag period of nearly $30 \mathrm{~d}$. After the lag period, $\mathrm{N}$ is released slowly for about $100 \mathrm{~d}$.

Nitrate concentration in leaf petiole reflects the $\mathrm{N}$ status of the whole plant and probable yield of almost all crops (Tanaka, 2003), and it is used to determine the topdressing time and $\mathrm{N}$ fertilizer amount (Sakaguchi et al., 2004). Because of increased soil $\mathrm{N}$ availability, the HV treatments showed greater nitrate levels in leaf petiole compared with the compost and bare treatments. Averaged across sampling dates, in 2016, nitrate levels in leaf petiole increased by $505 \%, 316 \%$, and $39 \%$ in the HV, HV + compost, and compost treatments, respectively; whereas in 2017, the HV, HV + compost, and compost treatments increased the nitrate levels in leaf petiole by $496 \%$, $226 \%$, and $20 \%$, respectively, compared with the bare treatment. It is noteworthy that despite the decreasing trend, the nitrate levels in the HV treatment continued to increase until 10 WAT compared with the other treatments, suggesting that HV application may reduce the basal and topdressing $\mathrm{N}$ fertilizer application, thereby leading to a sustainable tomato production system. Horimoto et al. (2002) reported similar findings; greater nitrate values were observed in plots incorporating $\mathrm{HV}$ residues than bare plots at 42 to $56 \mathrm{~d}$ after transplanting regardless of the additional $\mathrm{N}$ fertilizer rate. In our study, among the organic fertilizer treatments, compost showed the least influence on nitrate levels in leaf petiole, possibly the result of a lower decomposition speed of compost residues compared with HV residues. This assumption may be sustained by its lower SIN levels in both years compared with the HV treatment (Fig. 2). The HV + compost treatment showed an intermediate effect between the HV and compost treatments.

Soil $C$ and $N$ stocks. Winter cover cropping compared with bare fallow can maintain or increase organic $\mathrm{C}$ and $\mathrm{N}$ concentrations in soil by providing additional crop residue that increases $\mathrm{C}$ and $\mathrm{N}$ inputs to the soil (Kuo et al., 1997a, 1997b; Sainju et al., 2000). Averaged across years, application of $\mathrm{HV}$ and compost resulted in greater soil C stock mostly because of increased soil total $\mathrm{C}$ compared with the bare treatment. Soil C stock was $4.9 \%, 4.6 \%$, and $4.5 \%$ greater in the $\mathrm{HV}$, compost, and $\mathrm{HV}+$ compost treatments than in the bare treatment, respectively. The greater soil $\mathrm{C}$ stock in 2016 than in 2017 may be a result of a greater C input in $2016(2109 \mathrm{~kg} \mathrm{C} / \mathrm{ha})$ than 2017 (2052 kg C/ha) (Table 1). As with soil $\mathrm{C}$ stock, averaged across years, soil $\mathrm{N}$ stock increased by $15 \%, 7.3 \%, 5.5 \%$ in the compost, $\mathrm{HV}$, and $\mathrm{HV}+$ compost treatments, respectively, than in the bare treatment. It is noteworthy that there was a significant increase in soil N stock from 2016 to 2017 in the $\mathrm{HV}, \mathrm{HV}+$ compost, and bare treatments as a result of an increase in soil total $\mathrm{N}$. Increased soil total $\mathrm{N}$ in the bare treatment in 2017 was not expected; it may have resulted from $\mathrm{N}$ fertilizer input and/or from the decomposition of tomato roots left in the soil in 2016. Chemical $\mathrm{N}$ fertilizer may build up soil organic $\mathrm{N}$, because $10 \%$ to $50 \%$ of $\mathrm{N}$ applied to the soil is immobilized by microbes within the first year after fertilization

Table 7. Changes in soil $\mathrm{C}$ and $\mathrm{N}$ as influenced by hairy vetch (HV) and compost application using baseline 2015.

\begin{tabular}{lcccc}
\hline & \multicolumn{4}{c}{ Change by treatment using baseline ${ }^{\mathrm{z}}(\%)$} \\
\cline { 2 - 5 } Treatment & C stocks & N stocks & Total C & Total N \\
\hline Bare & -1.85 & 9.26 & -1.81 & 9.26 \\
Compost & 2.80 & 26.0 & 6.18 & 30.0 \\
HV & 3.00 & 17.3 & 7.75 & 22.6 \\
HV + compost & 2.55 & 15.4 & 8.06 & 21.7 \\
\hline
\end{tabular}

${ }^{\mathrm{z}}$ Changes in soil $\mathrm{C}$ and $\mathrm{N}$ stocks or soil total $\mathrm{C}$ and $\mathrm{N}$ were calculated with the following equation: Change $(\%)=$ $A-B / B$, where $A$ is the average soil $\mathrm{C}$ and $\mathrm{N}$ stocks or average soil total $\mathrm{C}$ and $\mathrm{N}$ measured after tomato cultivation in 2016 and 2017, and $B$ is the baseline soil $\mathrm{C}$ and $\mathrm{N}$ stocks or soil total $\mathrm{C}$ and $\mathrm{N}$ measured in 2015.
(Mulvaney et al., 2009; Shen et al., 1989). Increased soil $\mathrm{N}$ stock in the HV and HV + compost treatments would be expected because HV and compost residue effects on the soil $\mathrm{N}$ pool may last for a long time (Eghball et al., 2004; Sugihara et al., 2016; Wallingford et al., 1975). However, under openfield conditions, the effectiveness of $\mathrm{HV}$ in increasing the soil $\mathrm{N}$ pool may depend on the amount of residue added to the soil (Kuo et al., 1997b), soil temperature, and soil moisture. Because of low cover crop production [HV growth in the open field is constrained by lower temperatures compared with a plastic high tunnel (Fig. 1)] and abundant rainfall in Hokkaido, especially from July to September (annual average rainfall was $1442 \mathrm{~mm}$ in 2016, and $1032 \mathrm{~mm}$ in 2017), the effects of HV on the soil $\mathrm{N}$ pool may be short-lived.

To determine whether soil organic $\mathrm{C}$ and $\mathrm{N}$ sequestration have occurred, it is critical to establish the baseline stock before any treatment application, including cover crops (Olson et al., 2014). Thus, to assess gains or losses in soil $\mathrm{C}$ and $\mathrm{N}$ stocks after 2 years of cover cropping and compost application, we established the baseline stocks before the initiation of the experiment in 2015. In comparison with baseline stocks, both soil $\mathrm{C}$ and $\mathrm{N}$ stocks increased as a result of the incorporation of $\mathrm{HV}$ and compost residues. The gains in soil $\mathrm{C}$ stock were $3.0 \%, 2.8 \%$, and $2.6 \%$ in the $\mathrm{HV}$, compost, and HV + compost treatments (Table 7), respectively. However, the bare treatment showed a loss of soil C stock over a 2-year period. The loss of soil C stock $(-1.85 \%)$ was a result of a decrease in soil total $\mathrm{C}(-1.81 \%)$ (Table 7$)$, possibly because of accelerated decomposition of organic matter originally contained in the soil with $\mathrm{N}$ fertilization, water input, and increased aeration (Campbell and Souster, 1982; Mulvaney et al., 2009). Olson et al. (2014) also reported losses of soil C stock $(-4.7 \%)$ in no-cover crop fields under minimum tillage at a depth of 0 to $15 \mathrm{~cm}$ after 12 years of examination. As to soil $\mathrm{N}$ stock in our study, the gains were greater than those observed for soil C stock. Soil N stock increased by $26 \%, 17.3 \%, 15.4 \%$, and $9.26 \%$ in the compost, HV, HV + compost, and bare treatments, respectively. As opposed to soil total C and C stock, soil total $\mathrm{N}$ and $\mathrm{N}$ stock increased in the bare treatment after 2 years of cultivation compared with the baseline. The baseline approach enabled us to 
clarify that the greater soil $\mathrm{C}$ and $\mathrm{N}$ stocks in $\mathrm{HV}$ and compost treatments compared with the bare treatment were a result of soil $\mathrm{C}$ and $\mathrm{N}$ sequestration. Our results suggest that compost and $\mathrm{HV}$ treatments are more effective for improving soil $\mathrm{N}$ stock than soil $\mathrm{C}$ stock in topsoil over a 2-year period. The slow changes in soil total C or C stock observed in our study are consistent with other studies that soil organic $\mathrm{C}$ responds relatively slowly to management practices because of its large pool size (Franzluebbers et al., 1995; Haynes, 2000).

The benefits of cover crops and compost application on soil $\mathrm{C}$ and $\mathrm{N}$ have been recognized in previous studies. Brown and Cotton (2011) reported increased soil $\mathrm{C}$ and $\mathrm{N}$ in compost-amended soils than control soils (no compost application) at a soil depth of 0 to 15 $\mathrm{cm}$. Soil total $\mathrm{N}$ increased by $0.21 \%$ whereas soil organic $\mathrm{C}$ was 3 -fold greater in compostamended soils than control soils. Mc Vay et al. (1989) found greater soil organic $\mathrm{C}$ and $\mathrm{N}$ at the 5- to 10-cm depth in HV plots than in bare plots. Similarly, Sainju et al. (2003) reported increased $\mathrm{C}$ and $\mathrm{N}$ pools in cover crops (HV, crimson clover, rye) plots at a soil depth of 0 to $20 \mathrm{~cm}$ than in bare plots over 3 years of tomato cultivation.

Tomato yield, $N$ uptake, and $N$ recovery. Increased tomato fruit yield, shoot biomass, and $\mathrm{N}$ uptake in the $\mathrm{HV}$ treatment than in the bare treatment may have resulted from a greater N-rich biomass input in the soil (Sainju et al., 1999). HV-N promoted vigorous plant growth, resulting in greater biomass accumulation and fruit production. Sainju et al. (2000) reported greater tomato fruit yield, biomass, and $\mathrm{N}$ uptake with $\mathrm{HV}$ and crimson clover than with no cover crops. The positive effect of HV on tomato yield has also been reported by other researchers (Abdul-Baki et al., 1996; Araki et al., 2009; Horimoto et al., 2002; Sainju et al., 2003). Likewise, in our study, incorporation of compost resulted in increased tomato fruit yield, shoot biomass, and $\mathrm{N}$ uptake compared with the bare treatment. Because of increased soil N availability in 2017 compared with 2016, compost showed greater marketable and total yields. The HV + compost treatment showed intermediate effects between the $\mathrm{HV}$ and compost treatments for marketable yield, shoot biomass, and $\mathrm{N}$ uptake. Increased marketable yield in 2017 compared with 2016 was a result of a decrease in unmarketable yield from 2016 to 2017 (Table 5). Unmarketable fruits consisted mostly of catfacing disorder caused by the low temperatures at blooming time. Because of the need to have a longer harvest period, tomatoes were transplanted in June in both years, which is a cool month (Fig. 1). However, tomatoes grown in 2017 were transplanted 2 weeks later than tomatoes grown in 2016, so tomatoes grown in 2017 were exposed to lower temperatures for a shorter period than tomatoes grown in 2016. The greater $\mathrm{N}$ uptake in the $\mathrm{HV}$ treatment compared with the compost and $\mathrm{HV}+$ compost treatments was a result of increased $\mathrm{N}$ recovery that was 2 -fold greater than that in compost and $\mathrm{HV}+$ compost treatments. However, the $\mathrm{N}$ recovered by tomatoes in the $\mathrm{HV}$ treatment in this study was lower than $52 \%$ reported by Sainju et al. (1999).

\section{Conclusions}

Application of HV and livestock compost residues over a 2-year period influenced positively soil $\mathrm{C}$ and $\mathrm{N}$ stocks, soil $\mathrm{N}$ availability, $\mathrm{N}$ uptake, and tomato yield. Our hypotheses were supported partially by the data. The HV and compost treatments improved soil quality, $\mathrm{N}$ uptake, and tomato yield compared with bare fallow. Because of a greater $\mathrm{N}$ concentration and decomposition speed, the HV treatment was the most effective in increasing SIN, N uptake, and tomato fruit yield. The compost treatment, with a lower decomposition speed, was the most effective in increasing soil $\mathrm{N}$ stock and tomato fruit yield, especially during the second year. The combined application of $\mathrm{HV}$ and livestock compost showed intermediate effects between HV and compost. A comparison with baseline soil $\mathrm{C}$ and $\mathrm{N}$ stocks indicates that incorporation of HV and livestock compost residues in the soil increased $\mathrm{C}$ stock slightly, and increased $\mathrm{N}$ stock more significantly at the surface soil layer, whereas bare fallow showed soil C stock depletion. Based on our results, we recommend the use of $\mathrm{HV}$ incorporation and livestock compost in tomatoes grown in plastic high tunnels; however, the benefits of compost may be more pronounced from the second year onward. Because of unstable cover crop production in the northern region, a combined application of cover crops and compost may be one of the best practices to compensate for low-cover crop biomass production through increasing organic matter input to the soil, thereby improving soil quality and tomato yield.

\section{Literature Cited}

Abdul-Baki, A.A., J.R. Teasdale, R.F. Korcak, D.J. Chitwood, and R.N. Huettel. 1996. Freshmarket tomato production in a low-input alternative system using cover-crop mulch. HortScience 31:65-69.

Albaladejo, J., J. Lobez, C. Boix-Fayos, G.G Barbera, and M. Martinez-Mena. 2008. Longterm effect of a single application of organic refuse on carbon sequestration and soil physical properties. J. Environ. Qual. 37:2093-2099.

Araki, H., S. Hane, Y. Hoshino, and T. Hirata. 2009. Cover crop use in tomato production in plastic high tunnel. Hort. Environ. Biotechnol. 50:324-328.

Brady, N.C. and R.R. Weil. 2007. The nature and properties of soil. 14th ed. Prentice Hall, Englewood Cliffs, NJ.

Brown, S. and M. Cotton. 2011. Changes in soil properties and carbon content following compost application: Results of on-farm sampling. Compost Sci. Util. 19:88-97.

Campbell, C.A., F. Selles, G.P. Lafond, and R.P. Zentner. 2001. Adopting zero tillage management: Impact on soil $\mathrm{C}$ and $\mathrm{N}$ under long-term crop rotations in a thin Black Chernozem. Can. J. Soil Sci. 81:139-148.
Campbell, C.A. and W. Souster. 1982. Loss of organic matter and potentially mineralizable nitrogen from Saskatchewan soils due to cropping. Can. J. Soil Sci. 62:651-656.

Costa, J.M. and E. Heuvelink. 2018. The global tomato industry, p. 1-26. In: E. Heuvelink (ed.). Tomatoes. CABI, Wallingford, UK.

Eghball, B., D. Ginting, and J.E. Gilley. 2004. Residual effects of manure and compost applications on corn production and soil properties. Agron. J. 96:442-447.

Eghball, B., B.J. Wienhold, J.E. Gilley, and R.A. Eigenberg. 2002. Mineralization of manure nutrients. J. Soil Water Conserv. 57:470-473.

Franzluebbers, A.J., F.M. Hons, and D.A. Zuberer. 1995. Soil organic carbon, microbial biomass, and mineralizable carbon and nitrogen in sorghum. Soil Sci. Soc. Amer. J. 59:460-466.

Hargrove, W.L. 1986. Winter legumes as nitrogen source for no-till grain sorghum. Agron. J. 78:70-74.

Haynes, R.J. 2000. Labile organic matter as indicator of organic matter quality in arable and pastoral soils in New Zealand. Soil Biol. Biochem. 32:211-219.

Horimoto, S., H. Araki, M. Ishimoto, M. Ito, and Y. Fujii. 2002. Growth and yield of tomatoes in hairy vetch-incorporated and-mulched field. Jpn. J. Farm Work Res. 37:231-240.

Kong, A.Y.Y., J. Six, D.C. Bryant, R.F. Denison, and C. van Kessel. 2005. The relationship between carbon input, aggregation, and soil organic carbon stabilization in sustainable cropping systems. Soil Sci. Soc. Amer. J. 69:1078-1085.

Kuo, S., B. Huang, and R. Bembenek. 2001. Effect of winter cover crops on soil nitrogen availability, corn yield, and nitrate leaching. In: Optimizing nitrogen management in food and energy production and environmental protection. Proceedings of the 2nd international nitrogen conference on science and policy. The Scientific World 1(S2):22-29.

Kuo, S., U.M. Sainju, and E.J. Jellum. 1997a. Winter cover crop effects on soil organic carbon and carbohydrate in soil. Soil Sci. Soc. Amer. J. 61:145-152.

Kuo, S., U.M. Sainju, and E.J. Jellum. 1997b. Winter cover cropping influence on nitrogen in soil. Soil Sci. Soc. Amer. J. 61:1392-1399.

Mc Vay, K.A., D.E. Radcliffe, and W.L. Hargrove 1989. Winter legume effects on soil properties and nitrogen fertilizer requirements. Soil Sci. Soc. Amer. J. 53:1856-1862.

Muchanga, R.A., T. Hirata, and H. Araki. 2017. Hairy vetch becomes an alternative basal $\mathrm{N}$ fertilizer in low-input fresh-market tomato production in a plastic high tunnel. Hort. J. 86: 493-500.

Mulvaney, R.L., S.A. Khan, and T.R. Ellsworth 2009. Synthetic nitrogen fertilizers deplete soil nitrogen: A global dilemma for sustainable cereal production. J. Environ. Qual. 38:2295-2314.

Olson, K., S.A. Ebelhar, and J.M. Lang. 2014. Long-term effects of cover crops on crop yields, soil organic carbon stocks and sequestration. Open J. Soil Sci. 4:284-292.

Paustian, K., W.J. Parton, and J. Persson. 1992 Modelling soil organic matter in organicamended and nitrogen-fertilized long-term plots. Soil Sci. Soc. Amer. J. 56:476-488.

R Core Team. 2014. R: A language and environment for statistical computing. R Foundation for Statistical Computing, Vienna, Austria

Ranells, N.N. and M.G. Wagger. 1996. Nitrogen release from grass and legume cover crop monocultures and bicultures. Agron. J. 88:777-782. 
Sainju, U.M., B.P. Singh, and W.F. Whitehead 2000. Cover crops and nitrogen fertilization effects on soil carbon and nitrogen and tomato yield. Can. J. Soil Sci. 80:523-532.

Sainju, U.M., B.P. Singh, and S. Yaffa. 1999. Tomato and soil quality as influenced by tillage, cover cropping, and nitrogen fertilization, p. 104-113. In: J.E. Hook (ed.). Proceedings of the 22nd annual southern conservation tillage conference for sustainable agriculture. Georgia Agriculture Experiment Station, Special Publication 95. Tifton, GA.

Sainju, U.M., W.F. Whitehead, and B.P. Singh. 2003. Cover crops and nitrogen fertilization effects on soil aggregation and carbon and nitrogen pools. Can. J. Soil Sci. 83:155-165.
Sakaguchi, M., Y. Hikasa, and H. Nakazumi. 2004. Diagnostic technique for nitrogen of summerautumn harvest culture green-house tomato. Jpn. J. Soil Sci. Plant Nutr. 75:29-35.

Shen, S.M., P.B.S. Hart, D.S. Powlson, and D.S Jenkinson. 1989. The nitrogen cycle in the Broadbalk wheat experiment: ${ }^{15} \mathrm{~N}$-labelled fertilizer residues in the soil and in the microbial biomass. Soil Biol. Biochem. 21:529-533.

Sugihara, Y., H. Ueno, T. Hirata, and H. Araki. 2013. Uptake and distribution of nitrogen derived from hairy vetch used as a cover crop by tomato plant. J. Jpn. Soc. Hort. Sci. 82:30-38.

Sugihara, Y., H. Ueno, T. Hirata, M. Komatsuzaki, and H. Araki. 2016. Contribution of $\mathrm{N}$ derived from a hairy vetch incorporated in the previous year to tomato $\mathrm{N}$ uptake under hairy vetchtomato rotational cropping system. Hort. J. $85: 217-223$.

Tanaka, F. 2003. Plant nutritional diagnosis in Japan, with a special focus on crop quality and the environment. Food and Fertilizer Technology Center for the Asian and Pacific Regions. Document Database, Extension Bulletins, 9171.

Wallingford, G.W., L.S. Murphy, W.L. Powers, and H.L. Manges. 1975. Disposal of beef-feedlot manure: Effects of residual and yearly applications on corn and soil chemical properties. J. Environ. Qual. 4:526-531.

Wittwer, S.H. 1993. World-wide use of plastics in horticultural production. HortTechnology 3 : 6-19. 